\title{
EFEKTIVITAS MODEL PEMBELAJARAN BRAINSTORMING DALAM MENINGKATKAN HASIL BELAJAR MATEMATIKA SISWA
}

\section{EFFECTIVENESS OF BRAINSTORMING LEARNING MODEL IN IMPROVING STUDENTS' MATHEMATICS LEARNING OUTCOMES}

\author{
Edward Alfian'1), Nurdin Kaso'2), Sumardin Raupu ${ }^{3), ~ D w i ~ R i s k y ~ A r i f a n t i 4) ~}$ \\ 1,2,3,4)Fakultas Tarbiyah dan Ilmu Keguruan IAIN Palopo \\ edwardalfian01@gmail.com ${ }^{13}$, nurdin k@iainpalopo.ac.id ${ }^{2}$ ), sumardin_aldhy@iainpalopo.ac.id ${ }^{3)}$, \\ dwiriskyarifanti@gmail.com ${ }^{4)}$
}

\begin{abstract}
Abstrak
Penelitian ini bertujuan untuk mengetahui hasil belajar matematika siswa kelas VIII SMP Datuk Sulaiman Palopo Tahun Ajaran 2019/2020 melalui efektifitas model pembelajaran brainstorming. Penelitian ini merupakan jenis penelitian eksperimen. Populasi dalam penelitian ini adalah seluruh siswa kelas VIII SMP Datuk Sulaiman Palopo Tahun Ajaran 2019/2020. Pengambilan sampel menggunakan teknik cluster random sampling, sehingga diperoleh kelas $\mathrm{VIII}_{\mathrm{D}}$ sebagai kelas eksperimen dan kelas $\mathrm{VIII}_{\mathrm{E}}$ sebagai kelas kontrol. Instrumen penelitian menggunakan lembar observasi dan tes berupa pre-test dan posttest. Hasil penelitian ini menunjukkan bahwa: (1) rata-rata hasil belajar kelas eksperimen sebelum perlakuan yaitu 60,74; (2) rata-rata hasil belajar kelas kontrol sebelum perlakuan yaitu 64,73; (3) berdasarkan hasil uji hipotesis sebelum perlakuan diperoleh $t_{\text {hitung }} \leq$ $t_{\text {tabel }}$ atau $(-2,09 \leq 1,96)$; (4) rata-rata hasil belajar matematika kelas eksperimen setelah perlakuan yaitu 81,73; (5) rata-rata hasil belajar matematika kelas kontrol setelah perlakuan yaitu 58, (6) berdasarkan hasil uji hipotesis diperoleh $t_{\text {hitung }}>t_{\text {tabel }}$ atau $(7,39>1,96)$ artinya rata-rata hasil belajar matematika siswa yang diajar dengan model brainstorming pada pokok bahasan sistem persamaan linear dua variabel, lebih baik daripada rata-rata hasil belajar matematika siswa yang tidak diajar dengan model brainstorming pada pokok bahasan sistem persamaan linear dua variabel. Dengan demikian, dapat dinyatakan bahwa model Brainstorming efektif dalam meningkatkan hasil belajar matematika siswa kelas VIII SMP Datok Sulaiman Palopo.
\end{abstract}

Kata Kunci: efektif, model pembelajaran brainsorming, hasil belajar matematika

\begin{abstract}
This study aims to determine the mathematics learning outcomes of eight-grade students of Datuk Sulaiman Palopo Middle School Academic Year 2019/2020 through the effectiveness of the brainstorming learning model. This research is an experimental research. The population in this study were all eighth-grade students of Datuk Sulaiman Palopo Middle School Academic Year 2019/2020. Sampling uses cluster random sampling technique so that class VIII ${ }_{D}$ as an experimental class and class VIII $E$ as a control class. The research instrument used observation sheets and tests in the form of pre-test and post-test. The results of this study indicate that: (1) the average learning outcomes of the experimental class before treatment is 60.74 , (2) the average learning outcomes of the control class before treatment is 64.73; (3) based on the results of the hypothesis test before the treatment is obtained t count = table or $(-2.09$ 51.96); (4) the average mathematics learning outcomes of the experimental class after treatment is 81.73; (5) the average mathematics learning outcomes of the control class after treatment is 58, (6) based on the results of the hypothesis test obtained $t_{\text {count }}>t_{\text {table }}$ or (7.39> 1.96) meaning the average math learning outcomes of students taught with
\end{abstract}


brainstorming models on the subject of the linear equation system with two variable, better than the average mathematics learning outcomes of students who are not taught by brainstorming models on the subject of the linear equation system with two variable. Thus, it can be stated that the brainstorming model is effective in improving students' mathematics learning outcomes of class VIII Datok Sulaiman Palopo.

Keywords: effective, brainsorming learning model, mathematics learning outcomes

How to Cite: Alfian, E., Kaso, N., Raupu, S., \& Arifanti, D.R. (2020). Efektifitas model pembelajaran brainstorming dalam meningkatkan hasil belajar matematika siswa. Al asma: Journal of Islamic Education, 2(1), 54-64.

\section{PENDAHULUAN}

Pendidikan merupakan wahana untuk mengembangkan kualitas sumber daya manusia (SDM) yang diperlukan untuk mendukung terciptanya manusia yang cerdas serta mampu bersaing di era globlalisasi. Ilmu pendidikan berkembang seiring dengan teknologi yang semakin maju. Perkembangan ilmu pengetahuan dan teknologi yang begitu pesat menuntut setiap negara untuk memiliki keahlian dan keterampilan yang sesuai dengan kebutuhan dan tuntutan zaman sekarang (Hidayat, 2004: 2). Peningkatan kualitas pendidikan, terutama pendidikan di sekolah merupakan langkah awal peningkatan sumber daya manusia.

Salah satu faktor yang penting untuk mencapai tujuan pendidikan adalah proses pembelajaran yang dilakukan, sedangkan salah satu faktor penting untuk efektivitas pembelajaran adalah faktor evaluasi baik terhadap proses maupun hasil pembelajaran (Widoyoko, 2009). Pembelajaran pada hakekatnya adalah upaya untuk membimbing kegiatan belajar siswa yang didalamnya memuat kegiatan belajar dan mengajar. Salah satu kegiatan pembelajaran yang efektif adalah pembelajaran yang berpusat pada siswa (student centered learning) dimana guru hanya bertindak sebagai pembimbing dan fasilitator belajar (Syamsu, 2015: 19).

Setiap proses belajar mengajar selalu menghasilkan hasil belajar. Menurut Sanjaya (2006: 78), hasil belajar merupakan gambaran kemampuan siswa dalam memenuhi suatu tahapan pencapaian pengalaman belajar dalam satu kompetensi dasar. Lebih lanjut lagi oleh Sanjaya (2006: 35) bahwa hasil belajar siswa mencakup ranah kognitif, psikomotorik, dan afektif. Kriteria keberhasilan pembelajaran harus dilihat dari perkembangan ketiga aspek tersebut. Dengan demikian, hasil belajar matematika adalah hasil yang diperoleh dari kegiatan belajar matematika yang diketahui setelah diadakan evaluasi dalam bentuk tes tertulis, dalam hal ini aspek yang dinilai adalah aspek kognitif, aspek afektif dan aspek psikomotorik.

Hasil belajar yang dicapai siswa dipengaruhi oleh dua faktor utama yakni faktor internal (faktor yang datang dari diri siswa) dan faktor eksternal (faktor yang datang dari luar siswa). Seperti dikemukakan oleh Clark dalam Munir (2016: 118) bahwa hasil belajar siswa di sekolah 70\% dipengaruhi oleh kemampuan siswa dan 30\% dipengaruhi oleh lingkungan. Hasil belajar yang dicapai siswa setelah program belajar mengajar selesai digunakan guru untuk memperbaiki tindakan mengajarnya. Apabila hasilnya masih kurang, guru berkewajiban mengulang kembali bahan pelajaran tersebut sebelum dilanjutkan mengajarkan bahan yang lainnya (Baderiah, 2018: 83). 
Matematika merupakan salah satu mata pelajaran penting yang harus dipelajari oleh setiap siswa dalam berbagai jenjang pendidikan. Matematika dianggap sebagai mata pelajaran yang sangat menakutkan oleh sebagian besar siswa yang memengaruhi hasil belajar matematika siswa. Hasil belajar matematika sebagian siswa pun tidak menunjukkan hasil yang cukup memuaskan. Padahal diketahui bahwa matematika memegang peranan yang cukup penting dalam kehidupan manusia (Niharini \& Wahyuni, 2008: 101). Dalam mengatasi persoalan tentang kesulitan siswa dalam mempelajari matematika, maka diperlukan suatu metode pembelajaran efektif dan maksimal dalam proses belajar mengajar.

Berdasarkan hasil wawancara dan observasi di SMP Datok Sulaiman Putri Palopo, belum terdapat metode pembelajaran yang sesuai dan menarik dalam pembelajaran Matematika. Dalam kegiatan pembelajaran yang dilakukan di kelas, metode yang digunakan guru di sekolah tersebut ialah metode ceramah dan metode diskusi. Kedua metode tersebut tidak efektif dan maksimal untuk diterapkan karena didominasi oleh guru sehingga siswa menjadi pasif dalam pembelajaran. Terkadang jika soal yang diberikan guru sama dengan contoh soal yang telah diberikan sebelumnya, siswa akan percaya diri mengerjakan soal tersebut di depan kelas dan berani memberikan tanggapan tentang jawaban siswa lain yang salah. Namun, jika siswa diberi soal yang sedikit berbeda dari contoh sebelumnya mereka bingung mengaplikasikan konsep yang telah dipelajari, kepercayaan diri dan kegigihan dalam memecahkan masalah berkurang. Akhirnya siswa tidak dapat menyelesaikan soal tersebut dan merasa kesulitan untuk membuat kesimpulan pada akhir pembelajaran. Ini berarti hasil belajar matematika siswa masih rendah.

Berdasarkan penelitian yang dilakukan oleh Muh. Zaidi Tahir (2017) dengan menggunakan model pembelajaran yang sama mengenai efektivitas penerapan metode pembelajaran brainstorming tehadap hasil belajar peserta didik kelas V MI Muhammadiyah Pannampu Makassar. Hasil penelitiannya menunjukkan bahwa hasil belajar peserta didik pada kelas kontrol berdasar hasil perhitungan, maka dapat diketahui bahwa nilai mean empirik sebesar 205,00. Jika mengacu pada hasil penelitian, angka 205,00 berada pada kriteria sedang $(95 \leq 205 \leq 205)$. Sedangkan hasil belajar kelas eksperimen berdasarkan hasil perhitungan, maka dapat diketahui bahwa nilai emperis sebesar 318,00, berada pada kriteria tinggi (318 > 205). Dengan demikian, ada perbedaan yang signifikan antara hasil belajar peserta didik dengan menggunakan metode pembelajaran brainstorming dan yang tidak menggunakan metode pembelajaran brainstorming (Tahir, 2017).

Hasil penelitian yang dilakukan oleh Azis Muslim (2017) mengenai efektifitas model pembelajaran brainstorming terhadap kemampuan berpikir kreatif matematis peserta didik di SMA negeri 1 palopo, menunjukkan bahwa kemampuan berfikir kreatif matematis peserta didik yang diajar dengan menggunakan model pembelajaran brainstorming memperoleh nilai rata-rata 84,94 (Muslim, 2017). Selanjutnya penelitian yang dilakukan oleh Abdul Karim \& Fitriani (2017) mengenai penerapan metode brainstorming pada mata pelajaran IPS untuk meningkatkan hasil belajar kelas VIII di SMPN 4 rumbio jaya, hasil penelitian menunjukkan bahwa penerapan metode brainstorming dapat meningkatkan hasil belajar siswa kelas VIII di SMPN 4 Rumbio Jaya (Karim \& Fitriani, 2017). 
Model brainstorming adalah suatu teknik kegiatan belajar mengajar dimana terjadi dialog satu atau multi arah antara guru dengan siswa. Model pembelajaran brainstorming sering digunakan dalam diskusi kelompok untuk memecahakan masalah bersama, dan dapat juga digunakan secara individual. Pada diskusi kelompok, masing-masing individu mempunyai kesempatan yang sama untuk menyampaikan ide atau gagasannya, setelah semua ide atau gagasan tersampaikan, kemudian kelompok berdiskusi untuk menentukan solusi yang dianggap paling tepat. Sedangkan, pada individu berbeda pada tahap menampung ide atau gagasan, yaitu dilakukan oleh guru, yang kemudian dicatat sampai akhirnya ditentukan solusi yang sesuai (Hughes, 2016: 9).

\section{METODE PENELITIAN}

Jenis penelitian yang digunakan adalah penelitian eksperimen. Adapun desain yang digunakan dalam penelitian ini adalah desain true experimental design dengan bentuk pretest-postest control design. Populasi pada penelitian ini adalah seluruh siswa kelas VIII SMP Datok Sulaiman Putri Palopo tahun ajaran 2019/2020 yang berjumlah 170 siswa dan tersebar ke dalam 5 kelas. Adapun sampel yang terpilih adalah kelas VIII $_{d}$ dengan jumlah siswa 34 sebagai kelas eksperimen dan $\mathrm{VIII}_{\mathrm{e}}$ dengan jumlah siswa 34 sebagai kelas kontrol.

Teknik pengumpulan data pada penelitian ini yaitu teknik observasi, tes dan dokumentasi. Teknik observasi berguna untuk mengamati aktivitas siswa selama proses pembelajaran dan untuk mengetahui apakah proses pembelajaran tersebut berjalan sesuai rencana yang diinginkan. Alat ukur yang digunakan untuk observasi adalah lembar observasi siswa dan guru. Tes yang digunakan pada penelitian ini adalah tes hasil belajar matematika siswa yang terdiri dari dua macam yaitu pretest dan posttest. Dokumentasi digunakan untuk memperoleh data langsung dari tempat penelitian, meliputi buku-buku yang relevan, peraturan-peraturan, dan foto-foto.

Sumber data yang digunakan dalam penelitian ini berupa sumber data primer dan sumber data sekunder. Adapun teknik analisis data yang digunakan yaitu analisis statistik deskriptif dan inferensial. Analisis statistika deskriptif digunakan untuk mendeskripsikan karakteristik responden berupa persentase, rata-rata, median, modus, dan standar deviasi. Analisis statistika inferensial digunakan untuk menguji hipotesis penelitian dengan menggunakan uji t.

\section{HASIL DAN PEMBAHASAN}

Hasil analisis deskriptif berkaitan dengan skor pretest kelas kontrol. Untuk memperoleh gambaran karakteristik distribusi skor pretest kelas kontrol dapat dilihat dari Tabel 1.

Tabel 1. Statistik Deskriptif Pretest Kelas Kontrol

\begin{tabular}{cc}
\hline Statistik & Nilai Statistik \\
\hline Ukuran sampel & 34 \\
Rata-rata & 64,74 \\
Standar deviasi & 7,24 \\
Varians & 52,44 \\
Nilai terendah & 50 \\
Nilai tertinggi & 79 \\
\hline
\end{tabular}


Berdasarkan Tabel 1 menunjukkan bahwa hasil belajar matematika siswa pada kelas kontrol pretest dengan nilai rata-rata 64,74, standar deviasi sebesar 7,24, variansi sebesar 52,44, nilai terendah 50, dan nilai tertinggi 79. Untuk lebih jelasnya tentang frekuensi perolehan hasil pretest pada kelas kontrol dapat dilihat pada Gambar 1.

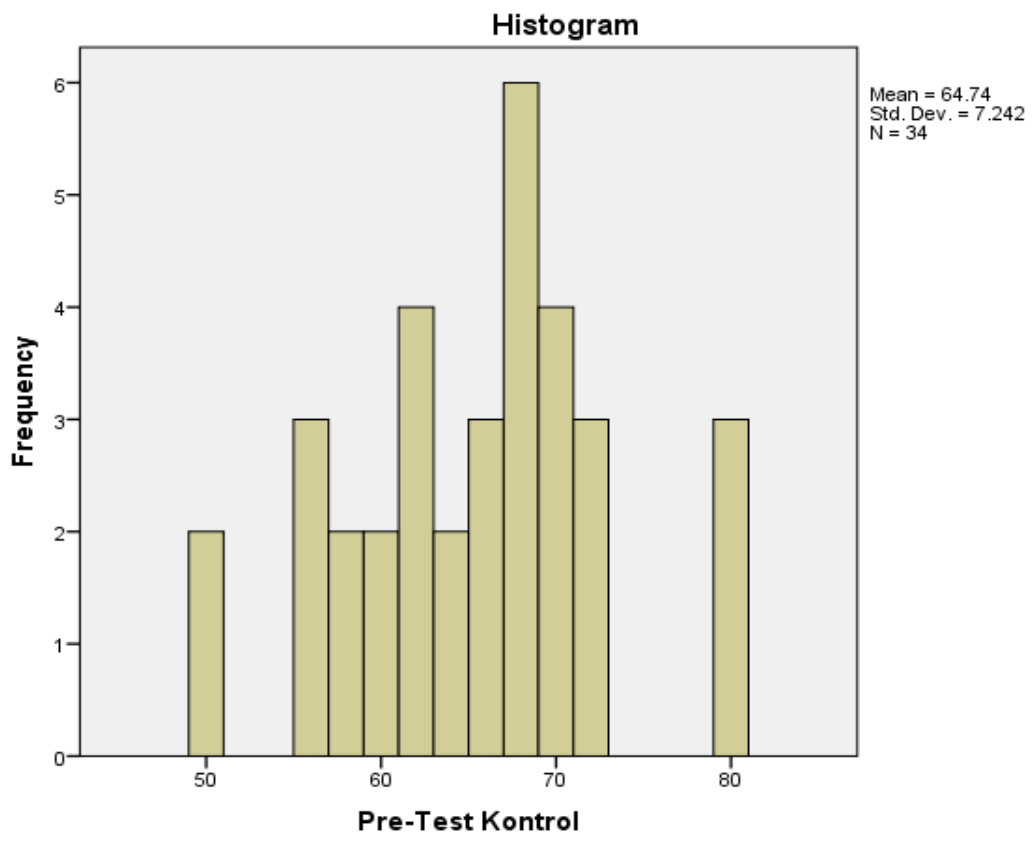

Gambar 1. Histogram Frekuensi Hasil Pretest Kelas Kontrol

Selanjutnya jika skor pretest kelas kontrol dikelompokkan ke dalam lima kategori maka diperoleh distribusi frekuensi dan persentase pretest kelas kontrol pada Tabel 2.

Tabel 2. Perolehan Persentase Hasil Pretest Kelas Kontrol

\begin{tabular}{cccc}
\hline Skor & Kategori & Frekuensi & Persentase(\%) \\
\hline $90-100$ & Sangat baik & 0 & $0 \%$ \\
$80-89$ & Baik & 0 & $0 \%$ \\
$70-79$ & Cukup & 6 & $18 \%$ \\
$60-69$ & Kurang & 19 & $56 \%$ \\
$0-59$ & Sangat kurang & 9 & $26 \%$ \\
\hline \multicolumn{2}{c}{ Jumlah } & 34 & $100 \%$ \\
\hline
\end{tabular}

Berdasarkan Tabel 2 di atas dapat dilihat bahwa dari 34 siswa pada kelas kontrol tidak terdapat siswa yang mendapat katergori sangat baik, sedangkan untuk kategori yang sangat kurang terdapat 9 siswa atau 18\%, untuk kategori kurang terdapat 19 siswa atau $56 \%$, dan untuk kategori cukup terdapat 6 siswa atau $26 \%$.

Hasil analisis statistik deskriptif berkaitan dengan skor pretest kelas eksperimen. Untuk memperoleh gambaran karakteristik distribusi skor pretest kelas eksperimen dapat dilihat dari Tabel 3. 
Tabel 3. Statistik Deskriptif Pretest Kelas Eksperimen

\begin{tabular}{cc}
\hline Statistik & Nilai Statistik \\
\hline Ukuran sampel & 34 \\
Rata-rata & 60,74 \\
Standar deviasi & 8,53 \\
Varians & 72,86 \\
Nilai terendah & 46 \\
Nilai tertinggi & 75 \\
\hline
\end{tabular}

Berdasarkan Tabel 3, hasil belajar matematika siswa pada kelas eksperimen pretest dengan nilai rata-rata 60,74, standar deviasi sebesar 8,53, variansi sebesar 72,86, nilai terendah 46, dan nilai tertinggi 75 . Untuk lebih jelasnya tentang frekuensi perolehan hasil pre-test untuk kelas eksperimen dapat dilihat pada Gambar 2.

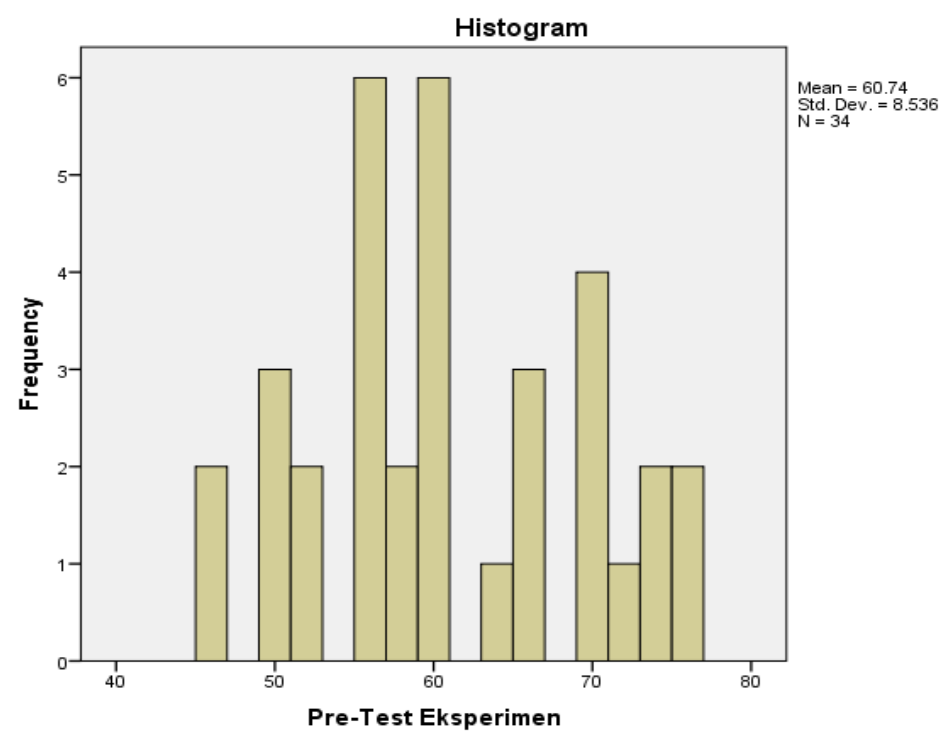

Gambar 2. Histogram Frekuensi Hasil Pretest Kelas Eksperimen

Selanjutnya jika skor pretest kelas eksperimen dikelompokkan ke dalam lima kategori maka diperoleh distribusi frekuensi dan persentase pretest kelas kontrol pada Tabel 4.

Tabel 4. Perolehan Persentase Hasil Pre-Test Kelas Eksperimen

\begin{tabular}{|c|c|c|c|}
\hline Skor & Kategori & Frekuensi & Persentase(\%) \\
\hline $90-100$ & Sangat baik & 0 & $0 \%$ \\
\hline $80-89$ & Baik & 0 & $0 \%$ \\
\hline $70-79$ & Cukup & 9 & $26 \%$ \\
\hline $60-69$ & Kurang & 10 & $30 \%$ \\
\hline $0-59$ & Sangat kurang & 15 & $44 \%$ \\
\hline \multicolumn{2}{|c|}{ Jumlah } & 34 & $100 \%$ \\
\hline
\end{tabular}

Berdasarkan Tabel 4 di atas dapat dilihat bahwa dari 34 siswa pada kelas Eksperimen tidak terdapat siswa yang mendapat katergori sangat baik, sedangkan untuk kategori yang sangat kurang terdapat 15 siswa atau 44\%, untuk kategori kurang terdapat 10 siswa atau 30\%, untuk kategori cukup terdapat 9 siswa atau 26\%. Hasil analisis 
deskriptif berkaitan dengan skor posttest kelas kontrol. Untuk memperoleh gambaran karakteristik distribusi skor posttest kelas kontrol dapat dilihat dari Tabel 5.

\begin{tabular}{cc} 
Tabel 5. Statistik Deskriptif Post-Test Kelas Kontrol \\
\hline Statistik & Nilai Statistik \\
\hline Ukuran sampel & 34 \\
Rata-rata & 58,82 \\
Standar deviasi & 13,81 \\
Varians & 190,87 \\
Nilai terendah & 30 \\
Nilai tertinggi & 85 \\
\hline
\end{tabular}

Berdasarkan Tabel 5, hasil belajar matematika siswa pada kelas kontrol post-test dengan nilai rata-rata 58,82, standar deviasi sebesar 13,81, variansi sebesar 190,87, nilai terendah 30, dan nilai tertinggi 85 . Untuk lebih jelasnya tentang frekuensi perolehan hasil post-test untuk kelas kontrol dapat dilihat pada Gambar 3.

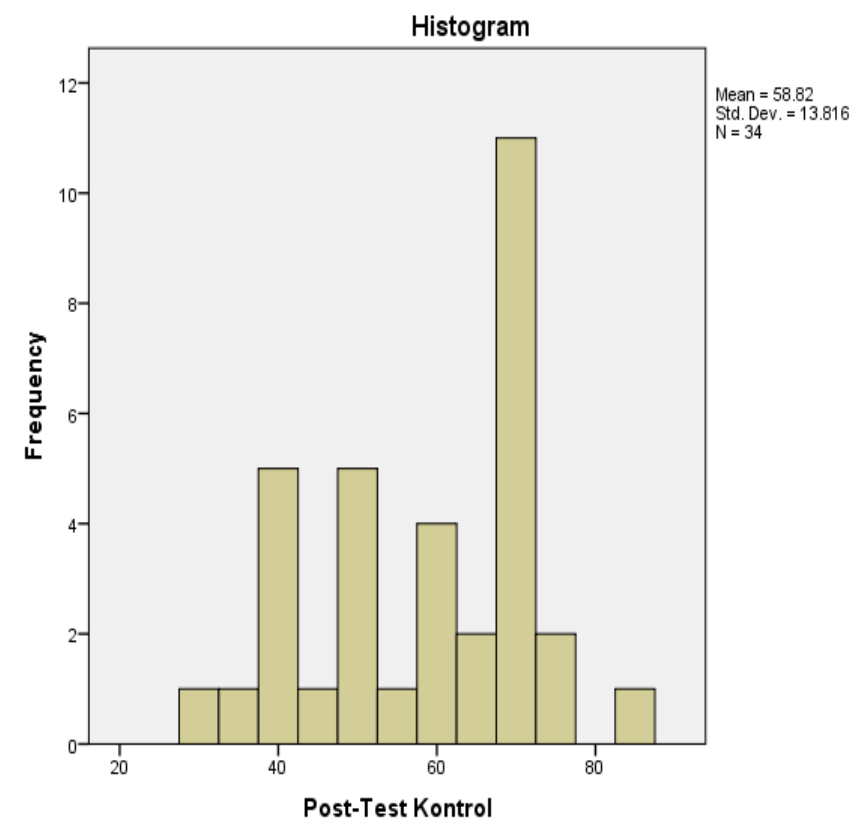

Gambar 3. Histogram Frekuensi Hasil Post-test Kelas Kontrol

Selanjutnya jika skor post-test kelas kontrol dikelompokkan ke dalam lima kategori maka diperoleh distribusi frekuensi dan persentase posttest kelas kontrol pada Tabel 6.

Tabel 6. Perolehan Persentase Hasil Posttest Kelas Kontrol

\begin{tabular}{cccc}
\hline Skor & Kategori & Frekuensi & Persentase(\%) \\
\hline $90-100$ & Sangat baik & 0 & $0 \%$ \\
$80-89$ & Baik & 1 & $3 \%$ \\
$70-79$ & Cukup & 12 & $35 \%$ \\
$60-69$ & Kurang & 7 & $21 \%$ \\
$0-59$ & Sangat kurang & 14 & $41 \%$ \\
\hline \multicolumn{2}{c}{ Jumlah } & 34 & $100 \%$ \\
\hline
\end{tabular}


Berdasarkan Tabel 6 bahwa dari 34 siswa pada kelas kontrol tidak terdapat siswa yang mendapat katergori sangat baik, sedangkan untuk kategori yang sangat kurang terdapat 14 siswa atau 41\%, untuk kategori kurang terdapat 7 siswa atau 21\%, untuk kategori cukup terdapat 12 siswa atau 35\%, dan untuk kategori baik terdapat 1 siswa atau $3 \%$.

Hasil analisis statistik deskriptif berkaitan dengan skor posttest kelas eksperimen. Untuk memperoleh gambaran karakteristik distribusi skor posttest kelas eksperimen dapat dilihat dari Tabel 7.

Tabel 7. Statistik Deskriptif Post-Test Kelas Eksperimen

\begin{tabular}{cc}
\hline Statistik & Nilai Statistik \\
\hline Ukuran sampel & 34 \\
Rata-rata & 81,74 \\
Standar deviasi & 9,97 \\
Variansi & 99,41 \\
Nilai terendah & 65 \\
Nilai tertinggi & 100 \\
\hline
\end{tabular}

Berdasarkan Tabel 7, hasil belajar matematika siswa pada kelas eksperimen posttest dengan nilai rata-rata 81,74, standar deviasi sebesar 9,97, variansi sebesar 99,41, nilai terendah 65 , dan nilai tertinggi 100 . Untuk lebih jelasnya tentang frekuensi perolehan hasil posttest untuk kelas eksperimen dapat dilihat pada Gambar 4.

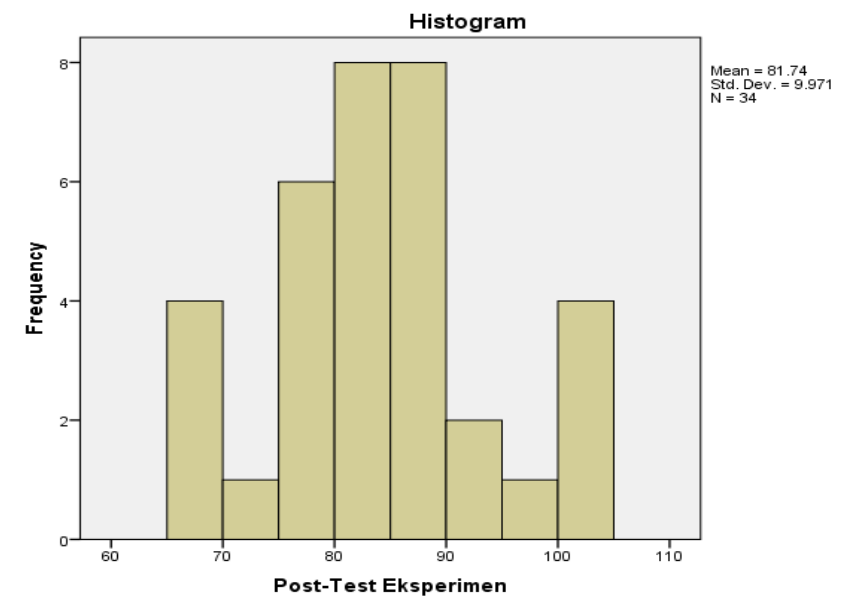

Gambar 4. Histogram Frekuensi Hasil Post-test Kelas Eksperimen

Selanjutnya jika skor post-test kelas eksperimen dikelompokkan ke dalam lima kategori maka diperoleh distribusi frekuensi dan persentase posttest kelas eksperimen pada Tabel 8.

Tabel 8. Perolehan Persentase Hasil Posttest Kelas Eksperimen

\begin{tabular}{cccc}
\hline Skor & Kategori & Frekuensi & Persentase(\%) \\
\hline $90-100$ & Sangat baik & 7 & $20 \%$ \\
$80-89$ & Baik & 16 & $48 \%$ \\
$70-79$ & Cukup & 7 & $20 \%$ \\
$60-69$ & Kurang & 4 & $12 \%$ \\
$0-59$ & Sangat kurang & 0 & $0 \%$ \\
\hline \multicolumn{2}{c}{ Jumlah } & 34 & $100 \%$ \\
\hline
\end{tabular}


Berdasarkan Tabel 8, dapat dilihat bahwa dari 34 siswa pada kelas Eksperimen terdapat 7 siswa atau 20\% yang mendapat katergori sangat baik dan terdapat 16 siswa atau $48 \%$ yang mendapat kategori baik, untuk kategori cukup terdapat 7 siswa atau $20 \%$, untuk kategori kurang terdapat 4 siswa atau $12 \%$.

Berdasarkan uji kesamaan dua rata-rata kondisi awal antara kelas kontrol dan kelas eksperimen, diperoleh deviasi standar gabungan (dsg) $=7,91$ dan $t_{\text {hitung }}=-2,0986$ dan $t_{\text {tabel }}=1,96$ dimana taraf signifikan $\alpha=0,05$. Karena $t_{\text {hitung }} \leq t_{\text {tabel }}$ atau $-2,09 \leq$ 1,96 .

Berdasarkan uji kesamaan dua rata-rata kondisi akhir antara kelas kontrol dan kelas eksperimen, diperoleh deviasi standar gabungan $(\mathrm{dsg})=12,04$ dan $t_{\text {hitung }}=$ 7,39 dan $t_{\text {tabel }}=1,96$ dimana taraf signifikan $\alpha=0,05$. Karena $t_{\text {hitung }}>t_{\text {tabel }}$ atau $7,39>1,96$. Maka dari itu dapat dikatakan bahwa rata-rata nilai kelas eksperimen lebih baik dari kelas kontrol. Dengan demikian, dapat dipahami bahwa efektifitas penggunaan model brainstorming dapat meningkatkan hasil belajar matematika siswa kelas VIII SMP Datok Sulaiman Putri Palopo.

Setelah diajar dengan menggunakan model pembelajaran brainstorming, yang berbeda pada kelas eksperimen dan kelas kontrol, terlihat bahwa hasil belajar matematika kelas tersebut berbeda secara nyata. Berdasarkan hasil analisis statistik pada data tahap akhir, yaitu uji beda dua rata-rata dengan menggunakan uji $t$. Dengan hasil tersebut, maka rata-rata hasil belajar matematika pada kelas eksperimen memiliki perbedaan yang signifikan dari rata-rata hasil belajar matematika kelas kontrol pada pokok bahasan sistem persamaan linear dua variabel. Terjadinya perbedaan nilai hasil belajar matematika tersebut, salah satunya disebabkan adanya perbedaan perlakuan pada dua kelas yaitu kelas eksperimen yang diajar dengan model pembelajaran brainstorming dan kelas kontrol yang tidak diajar dengan model pembelajaran brainstorming.

Pada pertemuan kedua dengan menerapkan model pembelajaran brainstorming dalam pelaksanaannya terjadi beberapa hambatan. Salah satu hambatan tersebut adalah timbul kegaduhan saat guru membagi siswa kedalam beberapa kelompok, sehingga berakibat cukup menyita banyak waktu untuk lebih memahamkan kepada siswa. Hambatan-hambatan yang terjadi pada pertemuan kedua perlahan-lahan mulai berkurang pada pertemuan selanjutnya. Siswa sudah mulai tertarik dengan model pembelajaran brainstorming.

Dari hasil observasi kelas kontrol, mulai dari pertemuan pertama hingga akhir pembelajaran, menunjukkan adanya peningkatan aktivitas namun tidak sebaik dengan hasil observasi kelas eksperimen. Dapat dijelaskan bahwa hasil observasi kelas eksperimen memiliki perbedaan dengan menggunakan model pembelajarann brainstorming dari hasil observasi kelas kontrol yang diajar dengan tidak menggunakan model pembelajaran brainstorming. Pada kelas eksperimen siswa lebih aktif dalam mengikuti pelajaran sedangkan pada kelas kontrol sangat nampak bahwa yang terlihat aktif dalam proses pembelajaran, hanya siswa yang sangat senang dengan pelajaran matematika. Hal ini mengakibatkan kemampuan siswa dalam menangkap isi materi yang disajikan menjadi lambat dan kurang mengena pada siswa. Selain itu, kelas yang tidak diajar dengan model brainstorming pada kelas kontrol, siswa tidak berani mengeluarkan pertanyaan dan pendapat mereka sehingga guru tidak bisa menganalisis kesulitan siswa dalam menyerap materi yang diajarkan. 


\section{SIMPULAN}

Berdasarkan hasil dari analisis statistik yang telah dilakukan, maka dapat diambil kesimpulan bahwa: (1) Hasil belajar matematika siswa yang tidak diajar dengan model pembelajaran Brainstorming sebelum perlakuan diperoleh rata-rata sebesar 64,73 dan setelah perlakuan diperoleh rata-rata sebesar 58,82; (2) Hasil belajar matematika siswa yang diajar dengan model pembelajaran brainstorming sebelum perlakuan diperoleh ratarata sebesar 60,74 dan setelah perlakuan diperoleh rata-rata sebesar 81,73; (3) Berdasarkan hasil uji hipotesis sebelum perlakuan diperoleh $t_{\text {hitung }} \leq t_{\text {tabel }}$ atau -2,0986 $\leq 1,96$ dan setelah perlakuan $t_{\text {hitung }}>t_{\text {tabel }}$ atau $7,39>1,96$. Artinya model pembelajaran brainstorming efektif dalam meningkatkan hasil belajar matematika siswa kelas VIII SMP Datuk Sulaiman Putri Palopo.

\section{DAFTAR PUSTAKA}

Anaguna N, Suhendra S. (2019). Student's learning achievement using Knisley learning model with brainstorming methode. IOP SCIENCE, 1157(2). Retrieved https://iopscience.iop.org/article/10.1088/1742-6596/1157/2/022129/meta

Aziz, M. A., dkk. (2015). Kemampuan Berfikir Kreatif dan Self-Efficacy Pesertas Didik Kelas X SMK Teuku Umar Semarang Dengan Model Pembelajaran Osborn. UJME, 4(3). Retrieved https://journal.unnes.ac.id/sju/index.php/ujme/article/view/9050

Azwar, Saifuddin. (2013). Reliabilitas Dan Validitas. Yogyakarta: Pustaka Pelajar.

Baderiah. (2018). Buku Ajar Pengembangan Kurikulum. Palopo: IAIN Palopo.

Faturrahman, Pupuh, and M. Sobry Sutikno. (2018). Strategi Belajar Mengajar Melalui Penanaman Konsep Umum Dan Konsep Islam, 1 Ed. Bandung: Refika Aditama, n.d.

Hidayat, S. (2004). Teori dan Prinsip Pendidikan. Tangerang: PT. Pustaka Mandiri.

Hughes, M. (2016). The Brainstorming Handbook. USA: Emereo Publishing.

Ishaq JJMAP, Bhat $\mathrm{H}$. (2019). Effect of brainstorming as a creative thinking method on the academic achievement of class ninth student. Journal Current Science, 20(6). Retrievedhttp://www.ijournal.scienceacad.com/index.php/Int/article/view/1225

Karim, A., \& Fitriani. (2017). Penerapan Metode Brainstorming Pada Mata Pelajaran IPS untuk Meningkatkan Hasil Belajar Kelas VIII di SMPN 4 Rumbio Jaya. PEKA, 5(1). Retrieved https://journal.uir.ac.id/index.php/Peka/article/view/1180

Maulidia, Anisya. (2016). Pengaruh Model Pembelajaran Brainstorming Terhadap Kemampuan Berpikir Kreatif Matematik Siswa Smp, Skripsi,. Bandung: Universitas Pasundan.

M.Subana, and et.al. (2000). Statistik Pendidikan. Bandung: Pustaka Setia.

Mukrimah, Syifa Siti. (2014). 53 Metode Belajar Dan Pembelajaran: Plus Aplikasinya. Bandung: Lembaga Penerbit Universitas Pendidikan Indonesia.

Munir, N. P. (2016). Pengaruh Kesadaran Metakognitif Terhadap Motivasi Belajar dan Kaitannya Dengan Hasil Belajar Matematika Siswa Kelas XI SMA Negeri Di Kota Pare-Pare. Al-Khwarizmi: Jurnal Pendidikan Matematika dan Ilmu Pengetahuan Alam, 4(2). Retrieved from https://ejournal.iainpalopo.ac.id/index.php/alkhwarizmi/article/view/256 
Muslim, A. (2017). Efektivitas Model Pembelajaran Brainstorming Terhadap Kemampuan Berpikir Kreatif Matematis Peserta Didik Di SMA Negeri 1 Palopo. Skripsi. IAIN Palopo.

Nasution. (2013). Berbagai Pendekatan Dalam Proses Belajar \& Mengajar. Jakarta: Bumi Aksara.

Nurdin. (2007). Model Pembelajaran Matematika Yang Menumbuhkan Kemampuan Metakognitif Untuk Menguasai Bahan Ajar. Surabaya: PPs UNESA.

Purwanto. (2011). Statistik Untuk Penelitian. Yogyakarta: Pustaka Pelajar.

Roestiyah. (2012). Strategi Belajar Menagjar. Jakarta: Rineka Cipta.

Sanjaya, W. (2006). Pembelajaran dalam Implementasi Kurikulum Berbasis Kompetensi. Jakarta: Kencana.

Syamsu, S. (2015). Strategi Pembelajaran Meningkatkan Kompetensi Guru (Catakan I). Makassar: Aksara Timur.

Tahir, M. Z. (2017). Efektivitas Penerapan Metode Pembelajaran Brainstorming terhadap Hasil Belajar Peserta Didik MI Muhammadiyah Pannampu Makassar. Skripsi. UIN Alauddin Makassar. Retrieved from http://repositori.uin-alauddin.ac.id/4906/

Widoyoko, E. P. (2009). Evaluasi Program Pembelajaran. Yogyakarta: Pustaka Pelajar. 